\title{
Evaluación de tratamientos de hidrofugación aplicados a piedras de catedrales andaluzas. III.-Ensayo de alteración acelerada en atmósfera contaminada
}

\author{
Evaluation of hydrophobic treatments applied \\ to stones used in andalusian cathedrals. \\ III.-Accelerated weathering test with polluted \\ atmosphere
}

VILLEGAS SÁNCHEZ, R.; VALE PARAPAR, J.F. Dpto. Ingeniería Química y Ambiental. Esc. Sup. Ingenieros Industriales. Univ. Sevilla

Fecha de recepción: 23-VII-93.

ESPAÑA

\section{$R E S U M E N$}

En el presente artículo se estudia el comportamiento de muestras de cinco tipos de piedra utilizados en catedrales andaluzas, tratadas con seis productos hidrófugos, sometiéndolas a un ensayo acelerado de alteración en atmósfera contaminada con $\mathrm{SO}_{2}$.

Para evaluar la alteración, además de la observación visual de las manifestaciones macroscópicas, se ha medido la variación de peso de las muestras expuestas y la cantidad de sulfato que permanece en la superficie tras el ensayo. Así mismo, se han detectado los cambios experimentados en las propiedades hidrófugas conferidas por los tratamientos, mediante la medida de propiedades relacionadas con el movimiento del agua.

\section{$S U M M A R Y$}

In this work we study the weathering resistance of samples of five types of stone used in Andalusian Cathedrals, treated with six water repellent products, by subjecting the samples to $\mathrm{SO}_{2}$ polluted atmosphere.

To evaluate the alteration of the samples, besides visual observation of macroscopic aspect, changes in weight and the quantity of sulfate that remains on the surface have been measured. Also properties related with water have been measured after the test to determine if there have been any changes in the hydrophobic characteristics.

\section{INTRODUCCIÓN}

Para el estudio se han utilizado cinco piedras calizas que pueden considerarse representativas de las utilizadas en los monumentos de la región andaluza. Las características principales de las mismas se presentan en la Tabla I.

En un artículo anterior (1) se han descrito las propiedades relacionadas con el acceso y el movimiento del agua en la piedra sin tratar y tratada con los diferentes productos: porosidad abierta, ángulo de contacto, tiempo de absorción de gotas, absorción por capilaridad e inmersión y velocidad de secado. Todos estos valores se ven lógicamente modificados tras la aplicación de los tratamientos.

\section{INTRODUCTION}

Five types of limestone that can be considered representatives of those used in the monuments of Andalucia, have been studied. Their main characteristics are shown on Table I.

In a previous paper (1) properties related with access and movement of water in stone have been studied: open porosity, contact angle, time for drop absorption, capillarity and inmersion water absorption and water drying rate. All these values are modified after the application of the treatments. 
TABLA I

Características de las piedras

\begin{tabular}{|c|c|c|c|c|c|c|}
\hline \multirow{2}{*}{ Piedra } & \multirow{2}{*}{ Catedral } & \multirow{2}{*}{ Tipo } & \multicolumn{2}{|c|}{ Comp. med. \% } & \multicolumn{2}{|c|}{$\%$ Porosidad } \\
\hline & & & $\mathrm{SiO}_{2}$ & $\mathrm{CaCO}_{3}$ & Macro & Micro \\
\hline Pto de Santa María & Sevilla & Calcarenita & 30 & 67 & 27 & 8 \\
\hline Espera & Sevilla & Caliza & 10 & 85 & 11 & 17 \\
\hline Ubeda & Baeza & Calcarenita & 30 & 65 & 20 & 8 \\
\hline Granada & Granada & Caliza & 3 & 95 & 19 & 6 \\
\hline \multirow{2}{*}{ Almería } & \multirow{2}{*}{ Almería } & \multirow{2}{*}{ Caliza dolomítica } & 7 & 53 & \multirow{2}{*}{17} & \multirow{2}{*}{27} \\
\hline & & & \multicolumn{2}{|c|}{$38 \% \mathrm{MgCO}_{3}$} & & \\
\hline
\end{tabular}

TABLE I

Characteristics of the stones

\begin{tabular}{|c|c|c|c|c|c|c|}
\hline \multirow{2}{*}{ Stone } & \multirow{2}{*}{ Cathedral } & \multirow{2}{*}{ Type } & \multicolumn{2}{|c|}{ Av. Comp., \% } & \multicolumn{2}{|c|}{$\%$ Porosity } \\
\hline & & & $\mathrm{SiO}_{2}$ & $\mathrm{CaCO}_{3}$ & Macro & Micro \\
\hline Pto de Santa María & Sevilla & Calcitic sandstone & 30 & 67 & 27 & 8 \\
\hline Espera & Sevilla & Limestone & 10 & 85 & 11 & 17 \\
\hline Ubeda & Baeza & Calcitic sandstone & 30 & 65 & 20 & 8 \\
\hline Granada & Granada & Limestone & 3 & 95 & 19 & 6 \\
\hline \multirow{2}{*}{ Almería } & \multirow{2}{*}{ Almería } & \multirow{2}{*}{ Dolomitic limestone } & 7 & 53 & \multirow{2}{*}{17} & \multirow{2}{*}{27} \\
\hline & & & \multicolumn{2}{|c|}{$38 \% \mathrm{MgCO}_{3}$} & & \\
\hline
\end{tabular}

TABLA II

Productos de tratamiento aplicados

\begin{tabular}{|l|l|l|l|}
\hline \multicolumn{1}{|c|}{ Producto } & \multicolumn{1}{|c|}{ Fabricante } & \multicolumn{1}{c|}{ Comp. del agente activo } & \multicolumn{1}{c|}{ Dilución } \\
\hline BS 28 & Wacker & Organosilícico (el fabricante no especifica más) & $5 \%$ en Xileno \\
$290 \mathrm{~L}$ & Wacker & Organosiloxano oligómero & $5 \%$ en Xileno \\
Baysilone & Bayer & Resina de silicona & $5 \%$ listo para usar \\
Tegosivin HL100 & Goldschmidt & Organosilícico monómero & $10 \%$ en Xileno \\
Consolidante 55050 & Ard Raccanello & Resina acrilsilicónica & $10 \%$ listo para usar \\
Paraloid B72 & Röhm \& Haas & Copolímero de metacrilato y etilmetacrilato & $10 \%(\mathrm{p} / \mathrm{v}$ ) en $1,1,1$ tricloroetano \\
\hline
\end{tabular}

TABLE II

Treatment products applied

\begin{tabular}{|c|c|c|c|}
\hline Product & Company & Activ agent & Dilution \\
\hline BS 28 & Wacker & Organosilicone (nothing else specified) & $5 \%$ in Xylen \\
\hline $290 \mathrm{~L}$ & Wacker & Oligomeric Organosiloxane & $5 \%$ in Xylen \\
\hline Baysilone & Bayer & Silicone resin & $5 \%$ ready to use \\
\hline Tegosivin HL100 & Goldschmidt & Monomeric organosilicic & $10 \%$ in Xylen \\
\hline Consolidante 55050 & Ard Raccanello & Acrylsiliconic resin & $10 \%$ ready to use \\
\hline Paraloid B72 & Röhm \& Haas & Metacrylate and etilmeta-crylate copolymer & $10 \%(w / v)$ in $1,1,1$ tricloroetane \\
\hline
\end{tabular}


Se han elegido seis productos hidrófugos que han sido aplicados por inmersión de las probetas. Las características de estos productos y las diluciones utilizadas se indican en la Tabla II.

Cabe resaltar de los resultados obtenidos en dicha evaluación de propiedades conferidas por los tratamientos, que los dos productos acrílicos, en comparación con los organosilícicos, originan menores disminuciones en los valores relacionados con la absorción de agua, a la vez que causan una mayor disminución en la velocidad de secado, por lo que puede esperarse que tengan peor comportamiento en lo que se refiere a la mejora de la resistencia a la alteración de las muestras.

En el presente artículo se estudia la resistencia a la alteración de estos tipos de piedra producida por el ataque de gases ácidos, sometiendo las muestras a un ensayo en atmósfera contaminada con $\mathrm{SO}_{2}$, incluyendo ciclos de humedad-secado. Tras dicho ensayo se ha medido:

- la variación de peso de las probetas,

- la cantidad de sulfato que permanece en la superficie,

- propiedades relacionadas con el acceso y evaporación de agua.

\section{ENSAYO DE ALTERACION ACELERADA CON ATMOSFERA CONTAMINADA}

El ensayo se ha llevado a cabo en una cámara de simulación ambiental $(2,3,4)$, en la cual se han mantenido las probetas durante 30 días, en una atmósfera con una concentración constante de 1.000 ppm de anhídrido sulfuroso, realizándose ciclos, con la siguiente duración de sus diferentes etapas:

- 24 horas de aire seco a $40^{\circ} \mathrm{C}$,

- 0,5 horas de simulación de lluvia,

- 23,5 horas de aire saturado de humedad a $40^{\circ} \mathrm{C}$.

El principal agente agresivo introducido en este ensayo es, naturalmente, el anhídrido sulfuroso; al ser todos los tipos de piedra estudiados de naturaleza carbonatada se forman sulfatos en la capa superficial. El sulfato cálcico (y el magnésico, en la piedra de Almeria) posee características diferentes a las del carbonato original, de manera que se crea una discontinuidad entre la zona atacada y aquella sin alterar,
Six water repellent products whose characteristics and concentrations are shown on Table II, have been applied by inmersion of the samples.

From the results obtained in this study, it may be pointed out that the two acrylic products, in comparison with organosilicic ones, have caused a lesser decrease in values related to water absorption and, at the same time, a greater decrease on the water drying rate so that it can be thought that their effect on the weathering resistance of the samples are worse.

In this work we have determined the resistance of these types of stone to the alteration due to acid gas attack by subjecting the samples to a test with $\mathrm{SO}_{2}$ polluted atmosphere and, at the same time, wetting-drying cycles. After the test we have measured:

- changes in weight of the samples,

- quantity of sulfate that remains on the surface,

- properties related to access and movement of water.

\section{POLLUTED ATMOSPHERE TEST}

The test has been carried out in an environmental simullation chamber $(2,3,4)$, where the samples have been maintained for 30 days in an atmosphere with a constant concentration of 1000 ppm $\mathrm{SO}_{2}$ with the following cycles:

- 24 hours dry air at $40^{\circ} \mathrm{C}$,

- 0,5 hours simullated rain,

- 23,5 hours humidity saturated air at $40^{\circ} \mathrm{C}$.

The main agresive agent in this test is sulfur dioxide; as all the types of stone studied were of calcitic nature sulfates are formed on the superficial layer. Calcium (and magnesium, on Almería stone) sulfate has different characteristics from the original carbonate, so that a discontinuity between attacked and non-attacked zones appears, which can originate alterations similar to those caused by low penetration treatments. 
que puede dar lugar a fenómenos similares a los causados por una baja penetración de los tratamientos.

Con posterioridad a la reacción química tienen lugar procesos de disolución y recristalización, que en ocasiones pueden provocar la aparición de eflorescencias, se forma una costra superficial de mayor dureza y, por último, la alteración puede llegar a la separación de esta capa superficial con diversas manifestaciones: fisuraciones, disyunciones, ampollas, pérdida de material, etc.

Las pérdidas de material se pueden deber a dos causas, la disolución de los sulfatos durante los periodos de lluvia y el posterior desprendimiento de partículas o trozos que quedan desligados. La primera de estas causas cobrará mayor inportancia en la piedra de Almería, dolomítica, en la que se formará sulfato magnésico, fácilmente soluble.

Los productos hidrófugos, mientras mantengan sus propiedades, limitarán el acceso del agua y, por tanto, los fenómenos de disolución y cristalización, disminuyendo además la velocidad de reacción del carbonato de la piedra con el $\mathrm{SO}_{2}$, relacionada con el contenido de humedad (5). No obstante, cuando la penetración del tratamiento es baja, pueden surgir fenómenos de separación de la capa superficial, similares a los debidos a la cristalización de sales (6).

La alteración de las probetas en este ensayo se ha contemplado desde el punto de vista macroscópico (alteración visual y variación de peso) y químico (sulfato que permanece en la superficie). La variación de peso se produce como consecuencia, por una parte, de un incremento producido por la conversión de carbonatos en sulfatos (de mayor peso molecular) $y$, por otra, de las pérdidas sufridas en los lavados con lluvia o en los desprendimientos de material. Algo similar sucede con la cantidad de sulfatos que quedan en la piedra, diferencia entre los formados y los eliminados. La comparación de variación de peso y contenido en sulfatos permite hacer una estimación de la importancia de las pérdidas de material.

En el caso de las muestras sin tratar, las pérdidas pueden superar a las ganancias $y$, en consecuencia, las probetas llegan, en ocasiones, a disminuir de peso, a pesar de contener una alta cantidad de sulfatos en la superficie. Por el contrario, en las probetas hidrofugadas, en las cuales se inhibe la solubilización del sulfato formado, se observará, en general, una buena correspondencia entre la ganancia de peso y el contenido de sulfatos.
Afterwards chemical reaction disolution and recrystallization processes take place that can cause the aparition of efflorescences, contribute to the formation of a hard superficial crust, and, lastly, weathering can finish with the detachment of this superficial crust in different ways: fissures, disjunctions, blistering, loss of material, etc.

Loss of material can be caused by the disolution of sulfates during the rain periods and by the following fall of particles or fragments that become detached. The first of these two causes will be more important on the case of Almeria stone, on which magnesium sulfate, easily soluble, will be formed.

Water repellent products, while maintaining their properties, will limit the access of water and, therefore, the disolution and recrystallization, so decreasing the rate of reaction of carbonate with $\mathrm{SO}_{2}$, related with water content of stone (5). Nevertheless, when penetration of the treatment is low it is posible that the detachment of the treated layer occurs, in a similar way that when caused by salt crystallization (6).

The weathering of the samples in this test has been studied from the macroscopic (visual alterations and changes in weight) and chemical points of view (sulfate that remains on the surface). The change in weight is due, on one hand, to the increment produced by the conversion of carbonate into sulfate (with higher molecular weight) and, on the other hand, to the loss of material suffered on the rain periods or by the falling of particles. The same occurs with the quantity of sulfate that remains on the surface, the difference between those formed and those disolved. The comparison of weight variations and sulfate contents makes it possible to evaluate the importance of losses of material.

In the cases of untreated samples losses can be superior to increments, and the samples experiment a weight decrease, even maintaining a high quantity of sulfates on the surface. On the contrary, on treated samples, on which the solubilization of sulfate is reduced, in general, a good corespondance between weight increment and sulfate content will exist. 
TABLA III

Comportamiento en los ensayos de alteración en atmósfera contaminada

\begin{tabular}{|c|c|c|}
\hline Tipo de piedra & Muestra sin tratar & Muestras tratadas \\
\hline $\begin{array}{l}\text { Puerto de } \\
\text { Santa Maria }\end{array}$ & $\begin{array}{l}\text { Alteración homogénea en toda la superficie, que se } \\
\text { manifiesta en la formación de una costra superficial } \\
\text { de sulfatos. El gran tamaño de los poros permite } \\
\text { absorber las posibles tensiones de cristalización y la } \\
\text { alteración macroscópica tarda en aparecer, comen- } \\
\text { zando con ligeras fisuraciones en vértices y aristas } \\
\text { (Figura 2). }\end{array}$ & $\begin{array}{l}\text { Todos los productos mejoran el comportamiento; las } \\
\text { probetas presentan alteraciones semejantes a las de } \\
\text { aquéllas sin tratar, que, en muchos casos, son } \\
\text { inapreciables a nivel macroscópico. Sin embargo, } \\
\text { debido a la alta porosidad de este tipo de piedra, los } \\
\text { contenidos de sulfato son muy elevados, al igual } \\
\text { que los incrementos de peso (Figura 11). En la Fi- } \\
\text { gura } 12 \text { aparecen las probetas tratadas con BS28. }\end{array}$ \\
\hline Úbeda & $\begin{array}{l}\text { Presenta mayor proporción de poros pequeños, lo } \\
\text { que es un índice de una mayor alterabilidad. En las } \\
\text { probetas sometidas al ensayo de alteración se ob- } \\
\text { servan eflorescencias repartidas por toda la superfi- } \\
\text { cie, más abundantes en vértices y aristas, donde } \\
\text { también se detectan disyunciones y fisuraciones } \\
\text { (Figura 3). }\end{array}$ & $\begin{array}{l}\text { Se observa, en general, una mayor alteración en las } \\
\text { probetas tratadas, exceptuando las correspondientes } \\
\text { a ARD y BS28. Esto puede deberse a una distribu- } \\
\text { ción irregular de los productos en el sistema poroso } \\
\text { de la piedra. En la Figura } 13 \text { aparecen probetas tra- } \\
\text { tadas con Tegosivin HL100 y en la } 14 \text { las tratadas } \\
\text { con Baysilone. } \\
\text { Como en los demás casos, existe relación entre } \\
\text { contenido de sulfatos e incremento de peso, con } \\
\text { valores intermedios de los mismos, como corres- } \\
\text { ponde a su porosidad (Figura 15). }\end{array}$ \\
\hline Granada & $\begin{array}{l}\text { Con porosidad algo más baja que Puerto de Santa } \\
\text { María y una proporción de microporos muy pequeña, } \\
\text { presenta un buen comportamiento. La alteración se } \\
\text { manifiesta en forma de eflorescencias puntuales, } \\
\text { produciéndose ligeros arrastres de material, que } \\
\text { acaban provocando, a la larga, un redondeamiento } \\
\text { de las probetas. (Figura 4). }\end{array}$ & $\begin{array}{l}\text { Tan sólo en algunas probetas han aparecido altera- } \\
\text { ciones significativas, por lo que puede decirse que } \\
\text { todos los tratamientos mejoran el comportamiento } \\
\text { de esta piedra, estando los incrementos de peso en } \\
\text { concordancia con los contenidos de sulfatos (Figura } \\
\text { 16). En la Figura } 17 \text { aparecen las probetas tratadas } \\
\text { con 290L. }\end{array}$ \\
\hline Espera & $\begin{array}{l}\text { Con porosidad muy variable y un alto porcentaje de } \\
\text { microporos, son mucho más alterables. La propor- } \\
\text { ción de sulfatos en superficie, y con ella la altera- } \\
\text { ción, aumenta con la porosidad, de forma que las } \\
\text { probetas más porosas quedan seriamente alteradas, } \\
\text { con fisuraciones y disyunciones, mientras que en las } \\
\text { de menor porosidad sólo se aprecian eflorescencias. } \\
\text { En algunos casos llegan a aparecer ampollas, } \\
\text { atribuibles a un desprendimiento originado por la } \\
\text { diferente naturaleza de la capa superficial de sulfa- } \\
\text { tos (Figura 5). }\end{array}$ & $\begin{array}{l}\text { En este tipo de piedra no se observa una mejoria } \\
\text { general de comportamiento de las probetas tratadas, } \\
\text { probablemente debido tanto a su gran alterabilidad } \\
\text { como a la menor penetración de los tratamientos. } \\
\text { Como consecuencia de su baja porosidad, los } \\
\text { contenidos de sulfatos y los incrementos de peso } \\
\text { son los menores de todos (Figura 18), llegando a } \\
\text { perder peso varias probetas. En numerosas mues- } \\
\text { tras aparecen eflorescencias, ampollas, fisuraciones } \\
\text { y disyunciones. Las menos alteradas son las tra- } \\
\text { tadas con Paraloid B72 y } 290 \mathrm{~L} \text {. En la Figura } 19 \text { se } \\
\text { muestran probetas tratadas con BS28. }\end{array}$ \\
\hline Almería & $\begin{array}{l}\text { La formación de una sal más soluble, como es el } \\
\text { sulfato magnésico, da origen a frecuentes y masivas } \\
\text { solubilizaciones y recristalizaciones, ocasionando } \\
\text { pérdidas de material y permitiendo que el ataque } \\
\text { progrese hacia el interior. Estas muestras son las } \\
\text { que presentan mayores alteraciones de todas las } \\
\text { sometidas al ensayo, con pérdidas de material y } \\
\text { formación de una costra pulverulenta, constituida por } \\
\text { eflorescencias y restos de arenizaciones; en varios } \\
\text { casos se observa una gran diferencia entre conte- } \\
\text { nido de sulfatos y variación de peso dada la gran } \\
\text { solubilización de aquéllos (Figura 6). }\end{array}$ & $\begin{array}{l}\text { Los productos organosilícicos la protegen de forma } \\
\text { efectiva, de manera que ninguna de las probetas } \\
\text { tratadas con ellos sufre una alteración significativa. } \\
\text { Los dos productos acrilicos tienen un comportamien- } \\
\text { to similar, con aparición de ampollas en toda la su- } \\
\text { perficie de las probetas. Este hecho puede } \\
\text { relacionarse con su escaso efecto hidrófugo, } \\
\text { confirmado por la rápida alteración que sufren estas } \\
\text { probetas en el ensayo de cristalización de sales. En } \\
\text { general no se aprecia una relación clara entre conte- } \\
\text { nido de sulfatos y variación de peso, ya que en la } \\
\text { mayoría de las probetas los incrementos de peso } \\
\text { son muy pequeños (Figura } 20 \text { ). En la Figura } 21 \\
\text { aparecen las probetas tratadas con Paraloid B72. }\end{array}$ \\
\hline
\end{tabular}


TABLE III

Behaviour on polluted atmosphere weathering tests

\begin{tabular}{|c|c|c|}
\hline $\begin{array}{l}\text { Type of } \\
\text { stone }\end{array}$ & Untreated samples & Treated samples \\
\hline $\begin{array}{l}\text { Puerto de } \\
\text { Santa María }\end{array}$ & $\begin{array}{l}\text { Homogeneus weathering on all the surface, in the } \\
\text { form of a superficial sulfate crust. The big pore size } \\
\text { makes it posible to absorb crystallization stresses } \\
\text { and macroscopical alteration progresses slowly, } \\
\text { begining with little fissures on tops and edges (Fi- } \\
\text { gure 2). }\end{array}$ & $\begin{array}{l}\text { All the products improve the behaviour of the sam- } \\
\text { ples, that suffer the same deterioration of those } \\
\text { untreated, even without macroscopic weathering in } \\
\text { many cases. Because of its high porosity, sulfate } \\
\text { contents are very important, as well as weight } \\
\text { increments (Figure 11). In Figure } 12 \text { samples treated } \\
\text { with BS } 28 \text { are shown. }\end{array}$ \\
\hline Úbeda & $\begin{array}{l}\text { It has a greater proportion of micropores, and } \\
\text { because of this its alterability is higher. On the sam- } \\
\text { ples there are efflorescences on all the surface, more } \\
\text { numerous on tops and edges, where also dis- } \\
\text { junctions and fissures appear (Figure 3). }\end{array}$ & $\begin{array}{l}\text { There are greater alterations on treated samples, } \\
\text { except on those treated with ARD and BS } 28 \text {. This } \\
\text { may be due to a irregular distribution of the } \\
\text { treatments inside the porous system of the stone. In } \\
\text { Figure } 13 \text { the samples treated with Tegosivin HL } 100 \\
\text { are shown and on Figure } 14 \text { those treated with } \\
\text { Baysilone. A relation between weight increment and } \\
\text { sulfate content also exists, these having variables } \\
\text { medium values, as it corresponds to the stone's } \\
\text { porosity (Figure 15). }\end{array}$ \\
\hline Granada & $\begin{array}{l}\text { With smaller porosity and very little proportion of } \\
\text { micropores, it has a good behaviour. Weathering } \\
\text { appears on the form of efflorescences with a slight } \\
\text { carrying away of material, which would cause, in the } \\
\text { end, a rounding of the sample (Figure 4) }\end{array}$ & $\begin{array}{l}\text { Only in a few samples there are significant altera- } \\
\text { tions, so we can say that the tratments improve the } \\
\text { behaviour of this type of stone. There is also a } \\
\text { relation between the weight increments and sulfate } \\
\text { contents (Figure } 16 \text { ). On Figure } 17 \text { samples treated } \\
\text { with } 290 \mathrm{~L} \text { are shown. }\end{array}$ \\
\hline Espera & $\begin{array}{l}\text { It is much more alterable, due to a very variable } \\
\text { porosity and a great percentage of micropores. Sul- } \\
\text { fate proportion, and in consequence deterioration, } \\
\text { increases with porosity; so, the most porous samples } \\
\text { result very deteriorated, with fissures and dis- } \\
\text { junctions, while the less porous ones only present ef- } \\
\text { florescences. Sometimes there are blisters due to the } \\
\text { different characteristics of the sulfate superficial layer } \\
\text { (Figure 5). }\end{array}$ & $\begin{array}{l}\text { There is not a general improvement of the behaviour } \\
\text { of treated samples in this type of stone, probably } \\
\text { due to its great alterability and the low penetration of } \\
\text { the products. Because of its low porosity, sulfate } \\
\text { contents and weight increments are the smallest of } \\
\text { all (Figure 18), even some samples lose weight. On } \\
\text { many samples there are efflorescences, blisters, } \\
\text { fissures and disjunctions. Those treated with } \\
\text { Paraloid B72 and } 290 \text { L are the less altered. In } \\
\text { figure } 19 \text { samples treated with BS } 28 \text { appear. }\end{array}$ \\
\hline Almería & $\begin{array}{l}\text { The formation of a soluble salt, such as magnesium } \\
\text { sulfate, gives rise to frequent solubilization and } \\
\text { recrystallization, which causes losses of material and } \\
\text { allow the attack to pregress toward the inner part of } \\
\text { the stone. These are the samples that show greatest } \\
\text { deteriorations, losses of material, formation of a pow- } \\
\text { dery crust composed by efflorescences and areni- } \\
\text { zations; on some cases there is a great difference } \\
\text { between sulfate content and weight increment, due } \\
\text { to the solubilization of sulfate (Figure } 6 \text { ). }\end{array}$ & $\begin{array}{l}\text { Organosilicic products have had a very good effect, } \\
\text { so that no sample has suffered significant alte- } \\
\text { rations. The two acrylic products have had a similar } \\
\text { behaviour: blisters appear on the whole surface. This } \\
\text { fact could be related to their bad hydrophobic effect } \\
\text { and the quick deterioration that these samples suffer } \\
\text { on the salt crystallization test (5). In general, there is } \\
\text { not a clear relation between weight increment and } \\
\text { sulfate content, because on the greater part of the } \\
\text { samples weight increments are very small (Figure } \\
20 \text { ). In Figure } 21 \text { the samples treated with Paraloid } \\
\text { B72 appear. }\end{array}$ \\
\hline
\end{tabular}




\section{RESULTADOS}

\subsection{Muestras sin tratar}

Observando la diversa morfología de las alteraciones es posible establecer diferencias entre la alterabilidad de los distintos materiales. Las probetas más alteradas son las de Espera y Almería, seguidas por las de Ubeda y, por último, las de Puerto de Santa María y Granada.

La proporción de sulfato en la capa superficial está claramente relacionada con la porosidad de las piedras, ya que una mayor porosidad permite que el ataque alcance zonas más internas. En la Figura 1 se muestran los valores correspondientes a cada tipo de piedra.

También se puede apreciar que, en general, existe una relación entre ganancia de peso y contenido de sulfatos, con la excepción de las probetas de Almería. En este caso, la solubilidad del sulfato magnésico debe ser, probablemente, la causa de que las pérdidas sean mucho mayores, lo que unido a su elevada porosidad permite que el ataque progrese hacia el interior, formando más sulfatos. Como consecuencia de todo ello, los contenidos de sulfato medidos son muy elevados y, en cambio, las variaciones de peso muy pequeñas $y$, en algunos casos, incluso negativas.

La alterabilidad no está relacionada, sin embargo, sólo con estos dos valores. Así, las probetas que a simple vista presentan un mayor grado de alteración, las de Espera (menor porosidad) y Almería (mayor porosidad), son las que presentan mayor cantidad de poros pequeños, en los que se generan las mayores tensiones de cristalización (7). En el caso de Espera, esto se ve agravado por la gran heterogeneidad del material, y en el caso de Almería por su composición química.

Se puede concluir, por tanto, que el tipo e intensidad de la alteración experimentado por un determinado material está relacionado tanto con sus características físicas (porosidad total y, especialmente, distribución de tamaños de poros), como con su composición química.

Una descripción más detallada de las alteraciones que experimentan las probetas sin tratar de cada uno de los tipos de piedra estudiados se recoge en la Tabla III.

\subsection{Probetas tratadas}

En este ensayo en atmósfera contaminada, al contrario de lo que sucede con el de cristalización

\section{RESULTS}

\subsection{Untreated samples}

It is posible to stablish differences on the alterability of the five types of stone, based on the different morphologies of decay. The most weathered samples are those from Espera and Almería, followed by those from Ubeda and lastly those from Puerto de Santa María and Granada.

The quantity of sulfate on the superficial layer is related to the porosity of stone, since a higher porosity makes it posible that the attack comes deeper inside the sample. On figure 1 the values for each type of stone are shown.

We can also observe that there is also a relation, in general, between weight increment and sulfate content, except on samples of Almería stone. In this case, the solubility of magnesium sulfate may probably be the cause that losses of material are much higher and that this united to the high porosity of the stone lets the attack progress inside the sample and so forming more sulfates. So, the sulfate contents are very high and the weight increments relatively small, negative in some samples.

However, the alterability does not depend only on these two parameters. The most weathered samples, from Espera (smallest porosity) and Almeria (highest porosity) are those which have the highest quantities of micropores, where crystallization stresses are greater (7). This fact is made worse by the great heterogeneity of Espera stone and by the chemical composition of Almeria one.

So it has to be pointed out that the type and intensity of weathering suffered by a material is determined by its physical (porosity and specially pore size distribution) and chemical characteristics.

A more detailed description of weathering of untreated samples of each type of stone are summarized on Table III.

\subsection{Treated samples}

In this test, opposed to what occurs in salt crystallization one (6), for what reffers to 


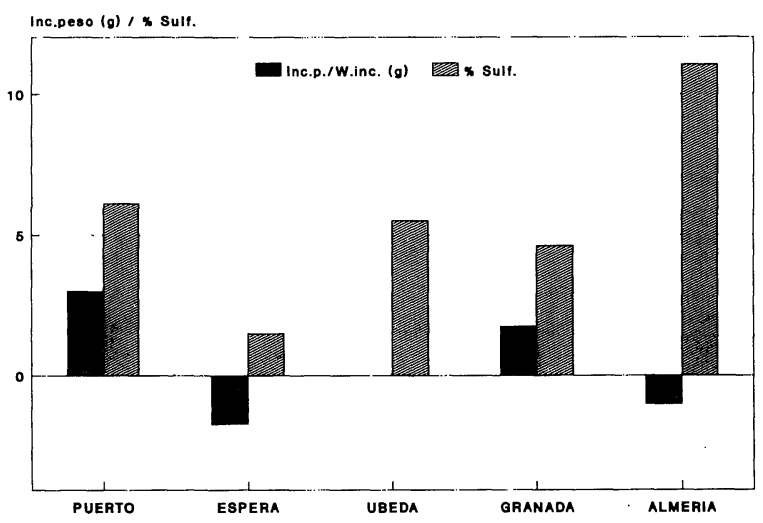

Fig. 1.-Probetas sin tratar.

Fig. 1.-Untreated samples.

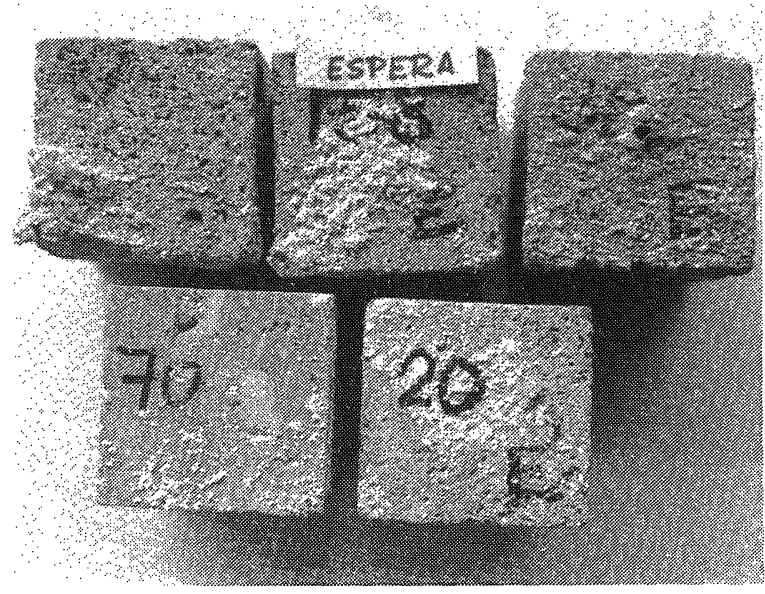

Fig. 3.-Probetas de Espera.

Fig. 3.-Espera samples.

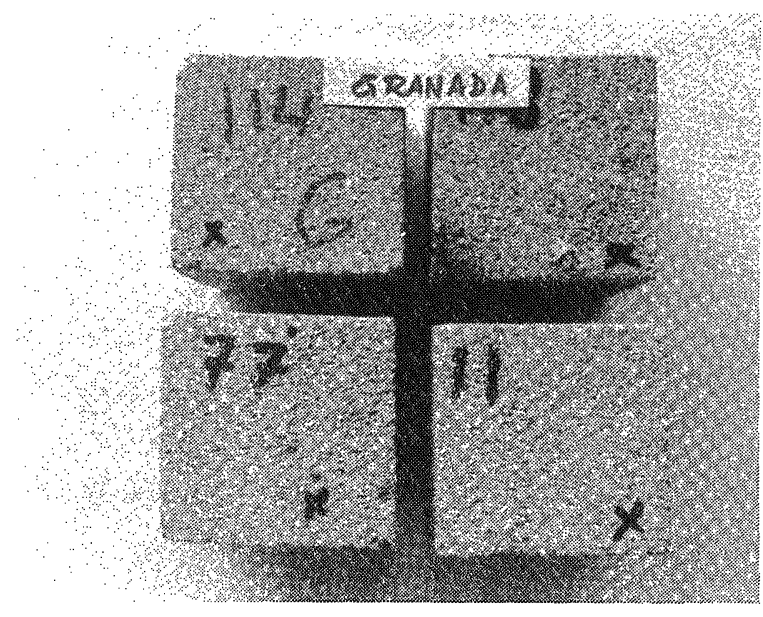

Fig. 5.--Probetas de Granada.

Fig. 5.--Granada samples.

MATERIALES DE CONSTRUCCIÓN, Vol. 43, n. ${ }^{\circ}$ 232, octubre/noviembre/diciembre 1993

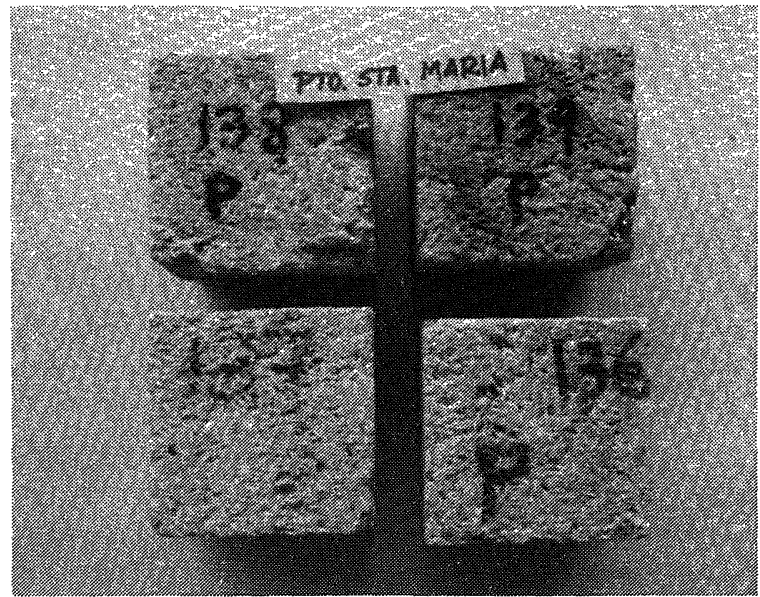

Fig. 2.-Probeta de Puerto de Santa Maria.

Fig. 2.-Puerto de Santa María samples.

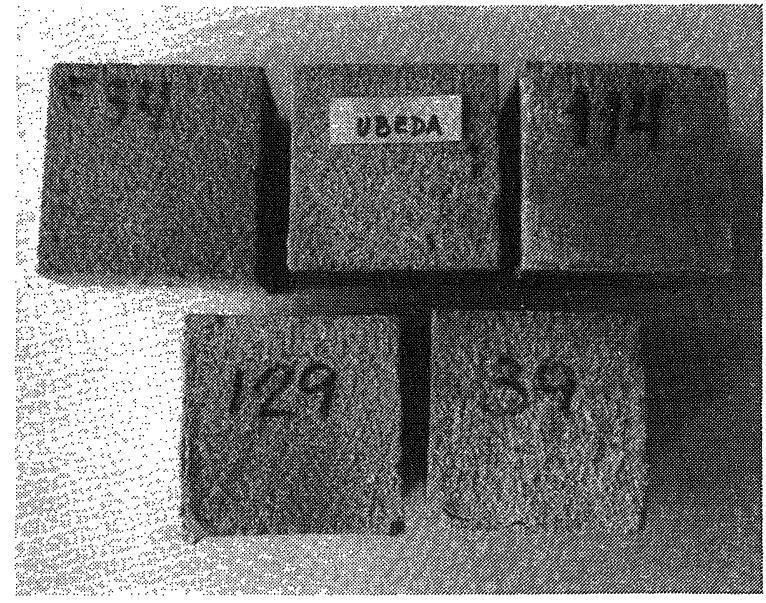

Fig. 4.-Probetas de Úbeda.

Fig. 4.-Úbeda samples

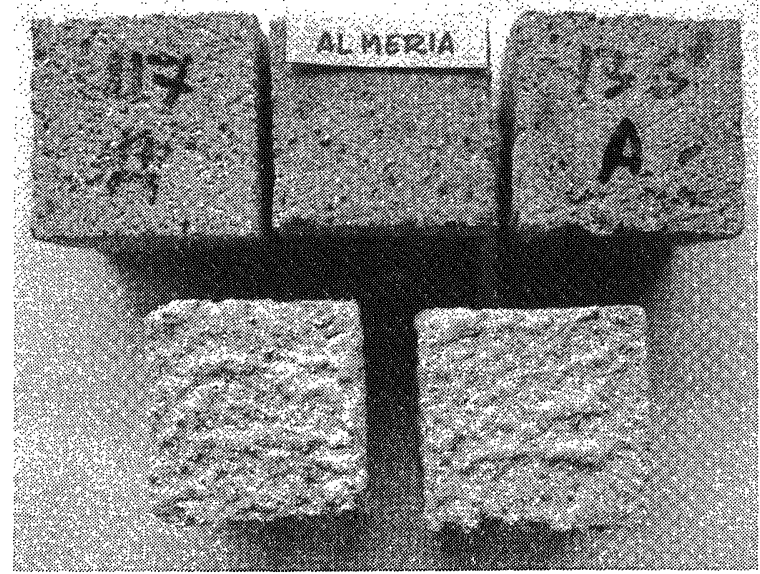

Fig. 6.-Probetas de Almeria

Fig. 6.-Almeria samples. 


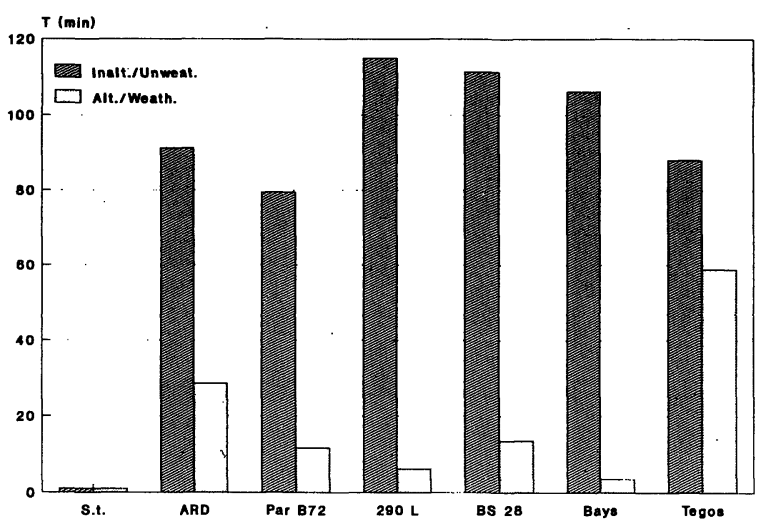

Fig. 7.-Granada absorción gotas.

Fig. 7.-Granada drop absorption.

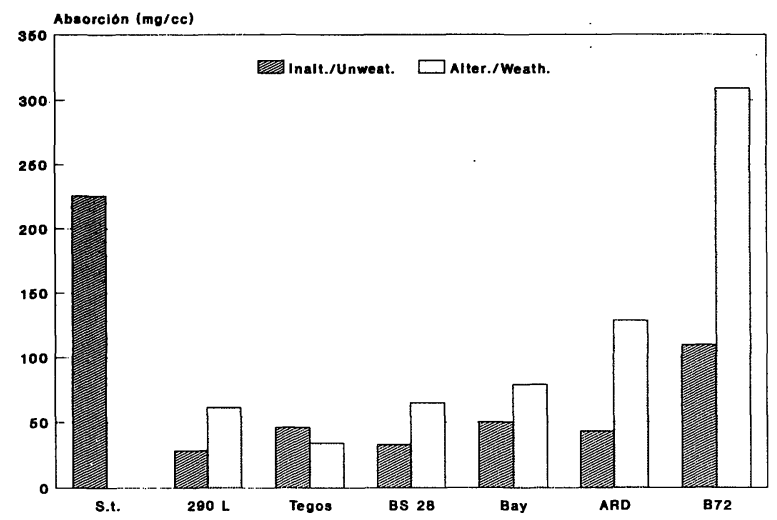

Fig. 9.-Espera absorción inmersión.

Fig. 9.-Espera inmersión absorption.

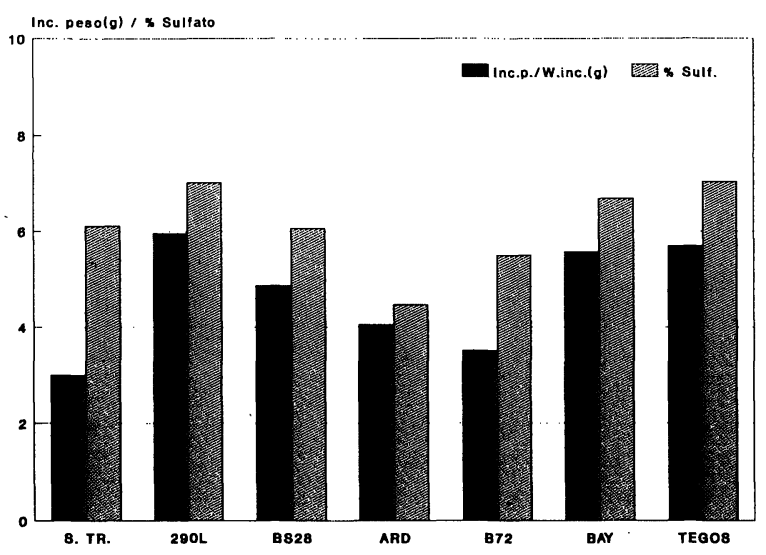

Fig. 11.-Puerto de Santa Maria.

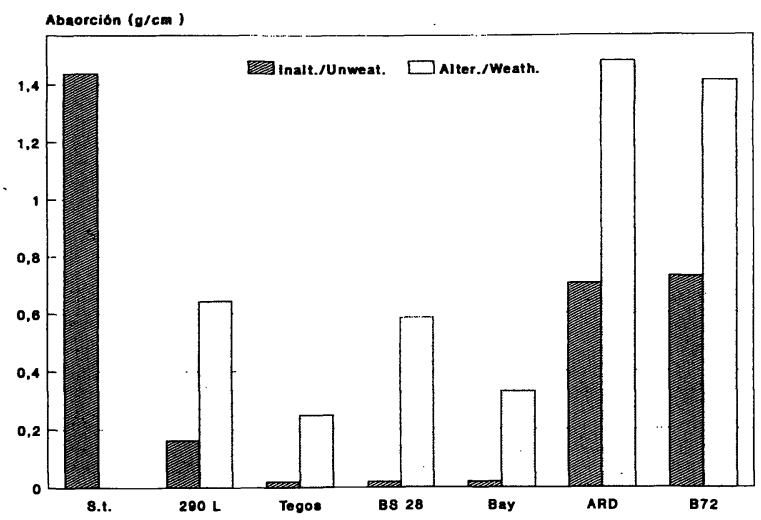

Fig. 8.-Almería absorción capilar.

Fig. 8.-Almeria capillarity absorption.

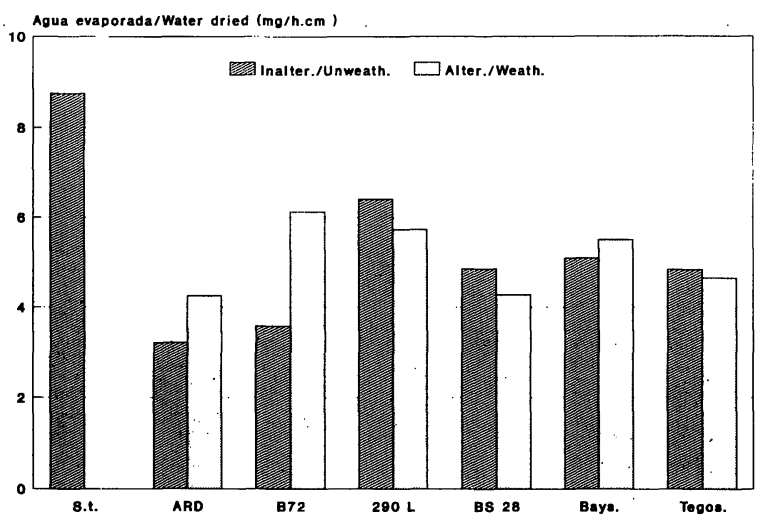

Fig. 10.-Úbeda velocidad de secado.

Fig. 10. -Úbeda water drying rate.

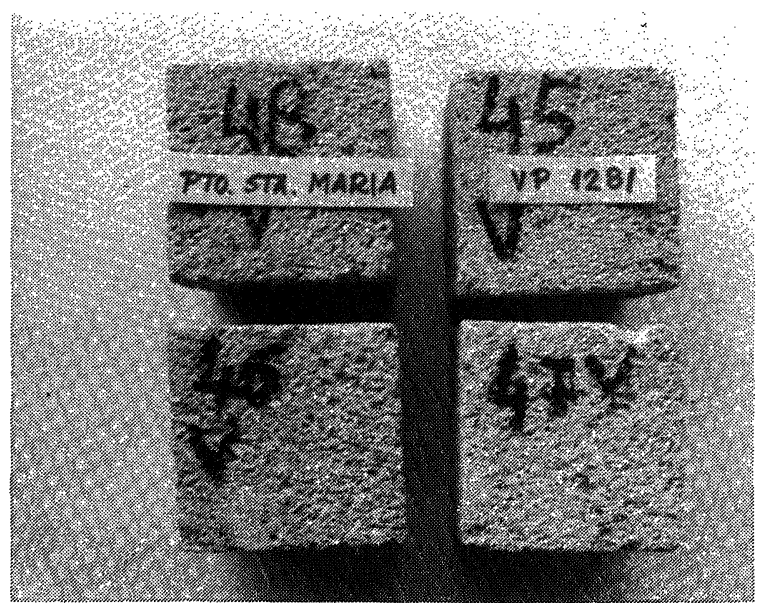

Fig. 12.-Probetas de Puerto de Santa Maria tratadas con BS 28.

Fig. 12. - Puerto de Santa Maria samples treated with BS 28. 
de sales (6), y en lo que se refiere a la morfología e intensidad de las alteraciones, no se aprecia un comportamiento que diferencie claramente a los productos acrílicos de los organosilícicos.

La hidrofugación superficial de las probetas se ve alterada radicalmente tras el ensayo. En efecto, las propiedades hidrófugas de la superficie disminuyen apreciablemente en todas las probetas, como se deduce de los valores del tiempo de absorción de gotas (Figura 7, valores correspondientes a las probetas de Granada), llegando a alcanzarse valores muy semejantes a los de las probetas sin tratar; esto indica una importante alteración superficial de todos los tratamientos.

En la absorción de agua por capilaridad o por inmersión sí se aprecian diferencias de comportamiento relacionadas con la naturaleza de los tratamientos; aunque en todos los casos aumentan los valores respecto a las probetas inalteradas, estos incrementos son bastante mayores en las probetas tratadas con los productos acrílicos (Figuras 8 y 9 correspondientes a las probetas de Almería y Espera, respectivamente, tras 7 días de absorción).

Por último, también es notable la diferencia en la variación de la velocidad de secado de las muestras. Mientras que en las probetas tratadas con organosilícicos se mantienen los valores previos a la experiencia de alteración, en las tratadas con acrílicos, que habian sufrido una disminución más acusada de esta característica (1) como consecuencia de la aplicación de dichos productos, se observa un aumento apreciable de la velocidad de secado después del ensayo (Figura 10 correspondiente a las probetas de Ubeda).

En el caso de los productos acrílicos, por tanto, esta pérdida de propiedades hidrófugas, tanto superficiales como globales, así como el aumento de la velocidad de secado, tienen que ser debidos a una alteración del producto en toda la probeta, sobre todo en el caso de Paraloid B72, cuya penetración es muy baja en todos los tipos de piedra.

Los organosilícicos mantienen relativamente bien sus caracteristicas hidrófugas, aunque desaparezcan en la superficie. La alteración de este tipo de tratamientos, pues, sólo tiene lugar en dicha zona superficial.

Entre estos productos organosilícicos puede destacarse BS28 como el que mejor comportamiento muestra en prácticamente todas las probetas, mientras que con Tegosivin HL100 morphology and intensity of alterations, there is not a characteristic behaviour that differentiate acrylic and organosilicic products clearly.

However, the hydrorrepellency of the samples is radically altered after the test, and in different ways depending on the type of product; the superficial hydrophobic effect decreases noticeably on every sample, as it can be deduced from the drop absorption time (Figure 7 , corresponding to Granada samples), that reaches values similar to those of the untreated samples; this makes it evident that a superficial deterioration of all the treatments has taken place.

On water absorption by capillarity or inmersion it is possible to see differences between the two types of treatments; although in every case the values are higher than those before the test, these increments are much greater on the acrylic treated samples (Figures 8 and 9 corresponding to Almería and Espera samples, respectively, after 7 days of absorption).

Lastly, differences on variation of water drying rate are also remarkable. While on the organosilicic treated samples the values are very similar to those before the test, on the acrylic treated ones (that have suffered a great decrease of this characteristic (1)) there is an important increment of water drying rate after weathering (Figure 10, corresponding to Ubeda samples).

This loss of hydrophobic properties, superficially (globally on the case of acrylic products), as well as the increment of water drying rate, may be explained by the deterioration of the product in the whole sample, specially for Paraloid B72, whose penetration in every type of stone is very small.

Organosilicic products maintain their hydrophobic characteristics quite well, although they disappear superficially. This points to a superficial deterioration of the treatments.

Among them, we can point up BS 28 for having the best behaviour on almost every samples, while with Tegosivin HL 100 greater deteriorations appear on the main part of the samples, in spite 


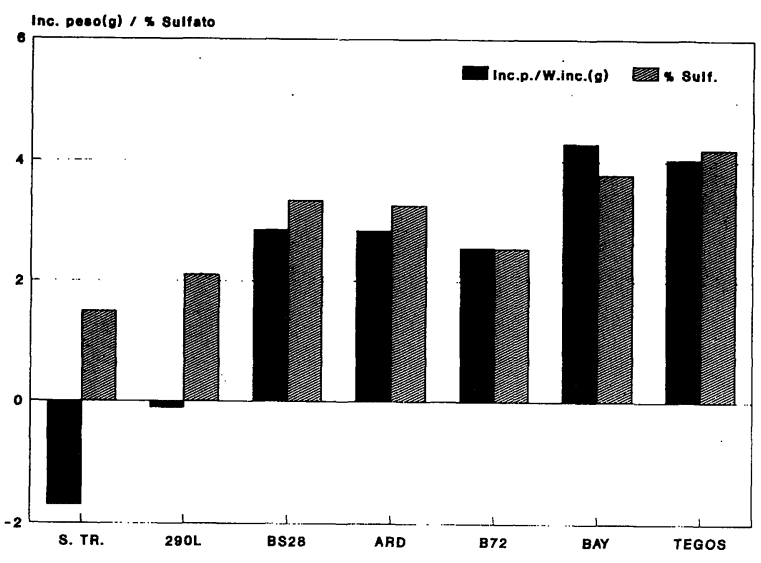

Fig. 13.-Espera.

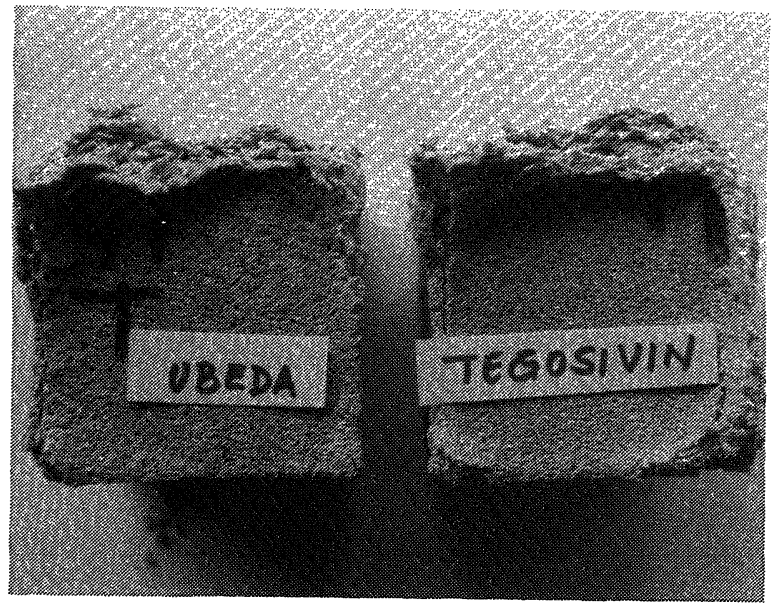

Fig. 15.-Probetas de Úbeda tratadas con Tegosivin HL100.

Fig. 15. - Úbeda samples treated with Tegosivin HL100.

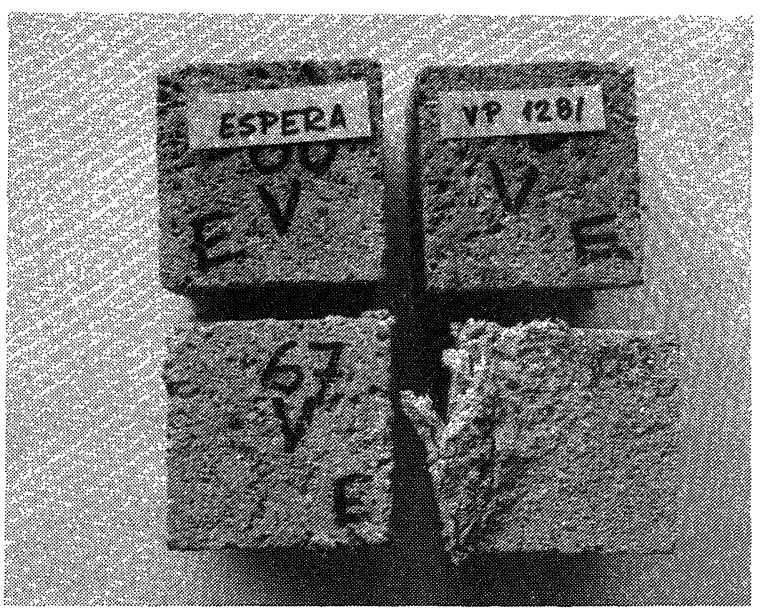

Fig. 14.-Probetas de Espera tratadas con BS 28.

Fig. 14.-Espera samples treated with BS 28.

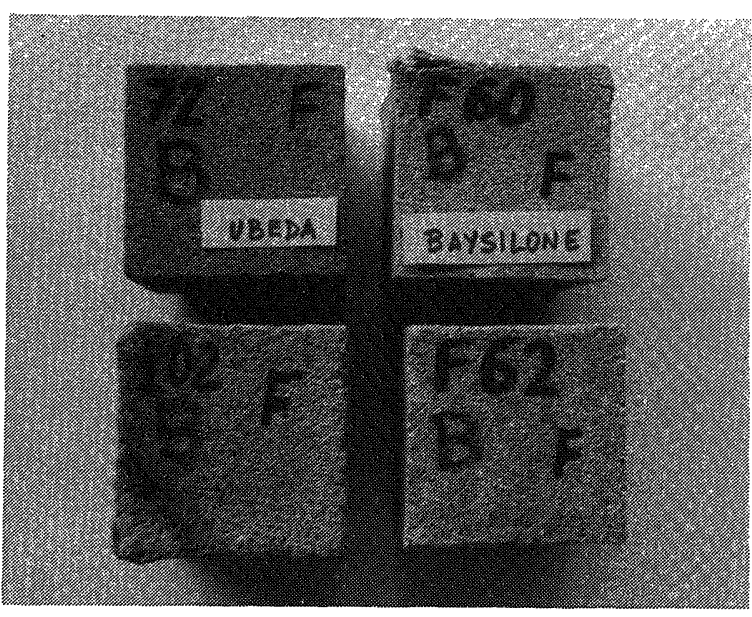

Fig. 16.-Probetas de Úbeda tratadas con Baysilone.

Fig. 16.-Úbeda samples treated with Baysilone.

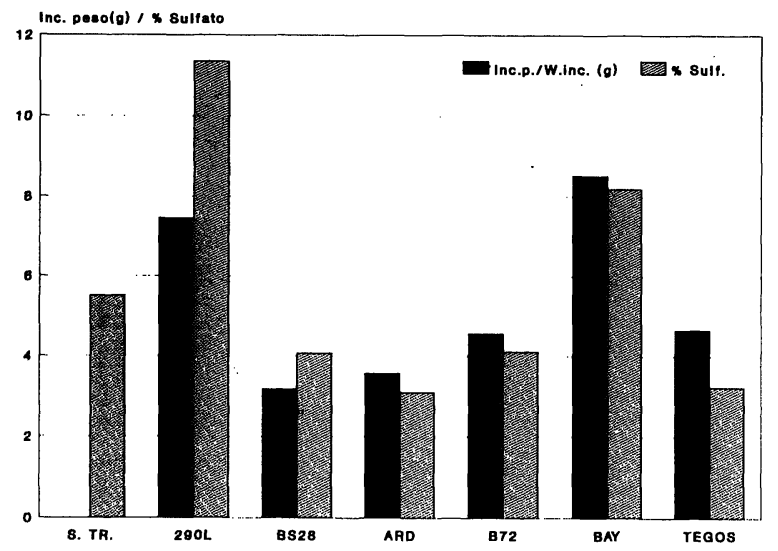

Fig. 17.-Úbeda 


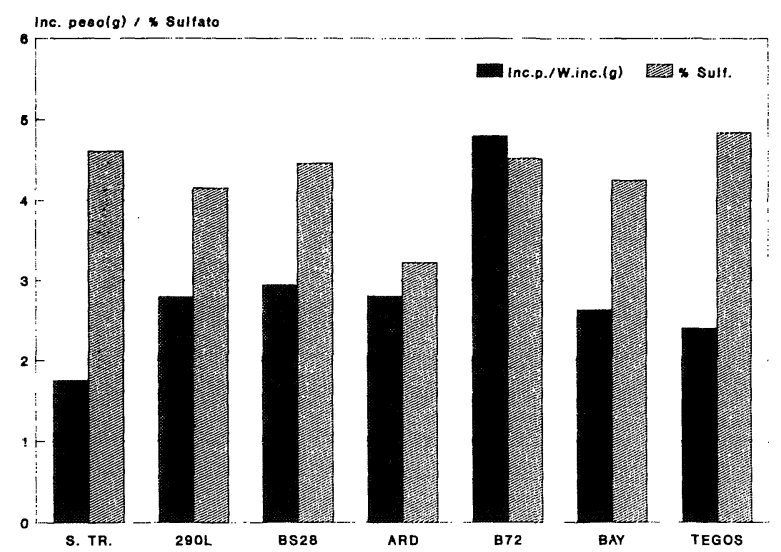

Fig. 18.- Granada.

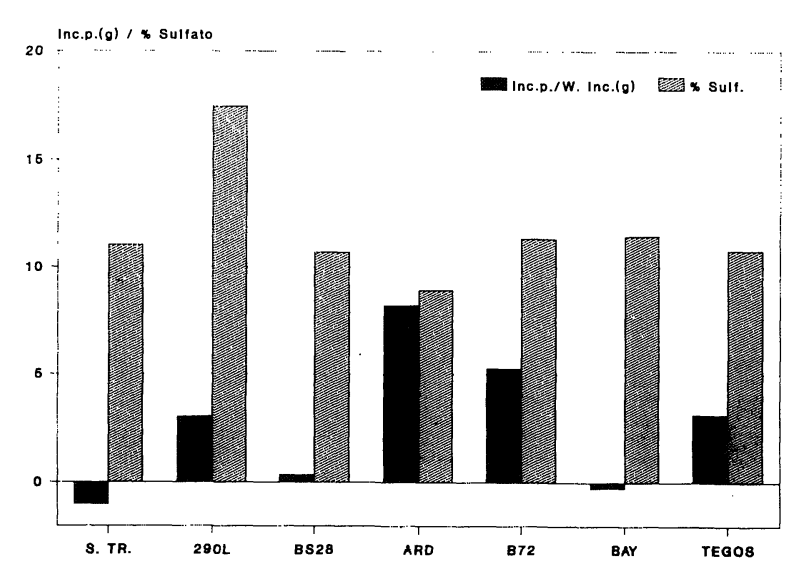

Fig. 20.-Almeria.

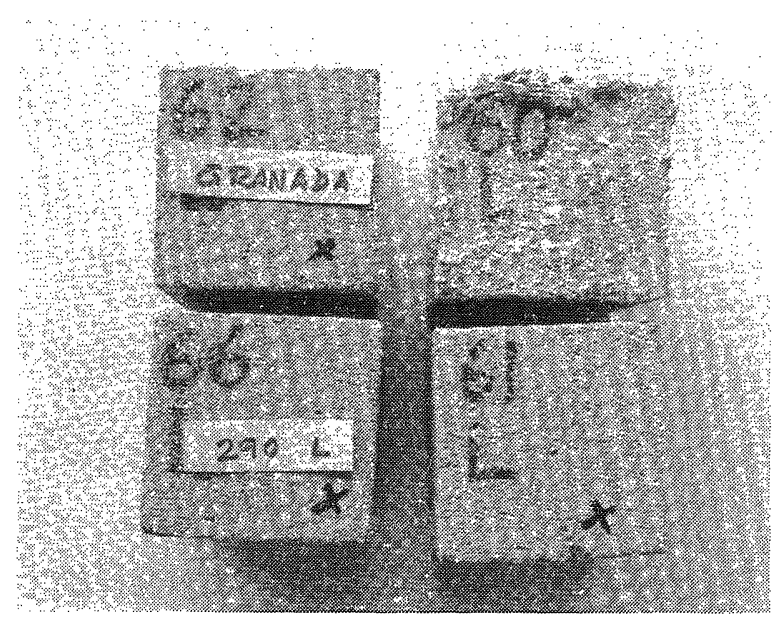

Fig. 19.---Probetas de Granada tratadas con $290 \mathrm{~L}$.

Fig. 19. - Granada samples treated with $290 \mathrm{~L}$

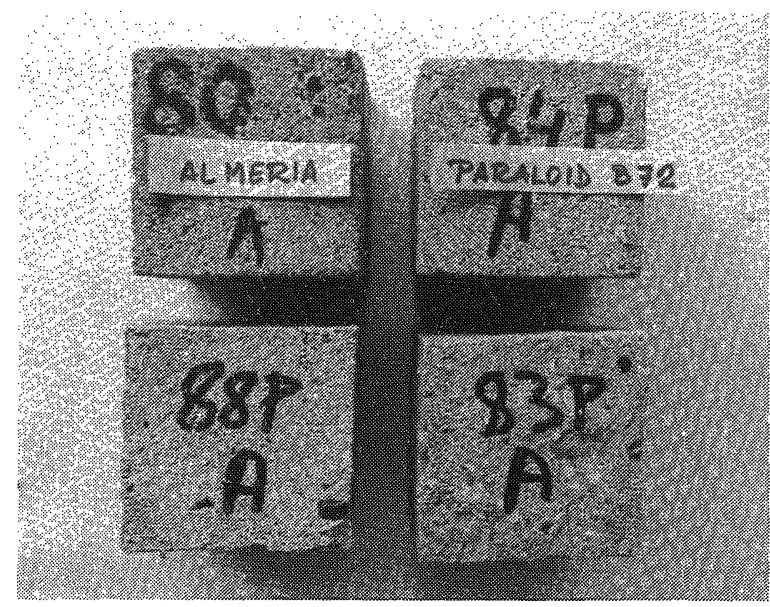

Fig. 21. - Probetas de Almeria tratadas con Paraloid B72.

Fig. 21. - Almeria samples treated with Paraloid B72.

of maintaining its water repellency without change, even superficially.

On Table III a detailed description of the alterations observed on treated samples of each type of stone appears. aparecen mayores alteraciones en la mayoría de las muestras, a pesar de que se mantiene prácticamente intacta la hidrofugación, incluso en la superficie de las muestras.

En la Tabla III se incluye, junto a las alteraciones experimentadas por las muestras sin tratar, una descripción más detallada de las alteraciones observadas en las muestras de cada tipo de piedra tratadas con los productos seleccionados. 


\section{CONCLUSIONES}

La alteración de las probetas sin tratar es función de las características físicas (porosidad y, especialmente, distribución de tamaños de poros) y químicas de cada tipo de piedra. En todas ellas tiene lugar, como consecuencia de la exposición a una atmósfera contaminada con $\mathrm{SO}_{2}$, una conversión de carbonato en sulfato, cuya posterior solubilización y recristalización provoca nuevas alteraciones y permite la progresión del ataque químico.

Los tipos de piedra que experimentan una alteración mayor son Espera (debido a su heterogeneidad y gran proporción de microporos) y Almería (como consecuencia de su composición química, con alto contenido de carbonato magnésico y alto porcentaje de microporos). Por el contrario Granada y Puerto de Santa María son las que resisten mejor el ensayo.

Todos los tratamientos protegen, en general, a todos los tipos de piedra, aunque, en algunos casos, se observan alteraciones más acusadas que en las probetas sin tratar.

También con carácter prácticamente general se puede indicar que el ensayo provoca una alteración profunda de los tratamientos, que pierden sus características hidrófugas, si bien, en la mayoría de los casos, sólo se ve afectada la superficie. Más concretamente, en las probetas tratadas con los productos acrílicos, toda la probeta sufre la desaparición de la hidrofugación, mientras que los productos organosilícicos la mantienen razonablemente bien, exceptuando la citada zona superficial.

\section{CONCLUSIONS}

Weathering of untreated samples is a function of physical (porosity and pore size distribution) and chemical characteristics of stones. On all the stones studied the conversion of carbonate into sulfate ocurrs, as a consequence of the exposure to $\mathrm{SO}_{2}$ atmosphere, and its later solubilization and recrystallization cause new alterations and allow the progresion of chemical attack.

The most deteriorated samples are those from Espera (due to its heterogeneity and great proportion of micropores) and Almería (due to its chemical composition, with a high content of $\mathrm{MgCO}_{3}$, and great proportion of micropores too). On the contrary, those from Puerto de Santa María and Granada are the ones that resist the test better.

Every treatment protects, in general, the samples, although in some cases more serious alterations appear.

Also in general, we can say that the test causes an important alteration of the treatments that lose their hydrorrepellent characteristics, although in most of the samples only superficially. On samples treated with acrylic products all the samples are affected by this loss of waterrrepellency, while organosilicic products keep it quite well, except the superficial area.

\section{BIBLIOGRAFIA}

(1) VILLEGAS, R., VALE, J.F.: Evaluación de tratamientos de hidrofugación aplicados a piedras calizas de Catedrales Andaluzas. Materiales de Construcción 223, 19-27, 1991.

(2) VALE, J.F., MARTIN, A.: Ensayos de materiales en atmósferas simuladas. I. Criterios para el diseño de sistemas de simulación. Materiales de construcción 189, 57-75, 1983.

(3) VALE, J.F., MARTIN, A.: Ensayos de materiales en atmósferas simuladas. II. Diseño de un sistema de simulación. Materiales de construcción 190-191, 53-68, 1983.

(4) VALE, J.F., MARTIN, A.: Ensayos de materiales en atmósferas simuladas. III. Evaluación de un sistema de simulación. Materiales de construcción 192, 57-77, 1983.

(5) HATSAGORTSIAN, Z.: Principes experimentaux et théoriques pour l'evaluation de durabilité de la pierre. Vth. Int. Congr. on Deterioration and Conservation of Stone, Lausanne, 195-204, 1985.

(6) VILLEGAS, R., VALE, J.F.: Evaluación de tratamientos de hidrofugación aplicados a piedras calizas de Catedrales Andaluzas. II. Ensayo de cristalización de sales. Materiales de Construcción

(7) MAMILLAN, M.: Etát actuel des methodes scientifiques apropiées a l'etude des propietés physiques des pierres alterées. Atti Conv. Int. Conservazione delle Sculture all'Aperto, Bologna, 133-142, 1969. 